\title{
Assessment and Mitigation of Cardiovascular Risk for Prostate Cancer Patients: A review of the evidence
}

Patrick Davey ( $\sim$ ppdavey@gmail.com)

Northampton General Hospital

Kyriacos Alexandrou

Ysbyty Gwynedd Hospital NHS Trust

\section{Research Article}

Keywords: prostate cancer, cardiovascular, agonists and antagonists, androgen deprivation therapy

Posted Date: April 9th, 2021

DOI: https://doi.org/10.21203/rs.3.rs-382729/v1

License: () (7) This work is licensed under a Creative Commons Attribution 4.0 International License. Read Full License 


\section{Abstract}

Background: Cardiovascular disease (CVD) is a common co-morbidity in patients with prostate cancer. In this review, we summarise the published literature on the association of cardiovascular risk with androgen deprivation therapy (ADT) treatment and explore the potential differences between the gonadotropinreleasing hormone $(\mathrm{GnRH})$ agonists and antagonists and the molecular mechanisms that may be involved. We also provide a practical outlook on the identification of underlying CV risk and explore the different stratification tools available.

Results: While not definitive, the current evidence suggests that $\mathrm{GnRH}$ antagonists may be associated with lower rates of certain $\mathrm{CV}$ events vs agonists, particularly in patients with pre-existing CVD. We have reached this conclusion as the highest-grade evidence from randomised clinical trials comparing GnRH agonists verses antagonists is uniform in finding lower $\mathrm{CV}$ event rates with $\mathrm{GnRH}$ antagonists. Risk reduction strategies such as lifestyle advice, consideration of ADT modality, and co-medications may help to reduce $\mathrm{CV}$ risk factors and improve outcomes in prostate cancer patients receiving ADT.

Conclusions: Given all the data that is currently available, identification of baseline CV risk factors may be key to risk mitigation in patients with prostate cancer receiving ADT.

\section{Introduction}

Androgen deprivation therapy (ADT) is the standard of care for men with advanced hormone dependent prostate cancer. Currently available pharmaceutical ADT's include luteinising hormone-releasing hormone (LHRH) agonists; leuprorelin, goserelin, triptorelin and buserelin acetate and the gonadotrophin releasing hormone (GnRH) antagonist; degarelix. The therapeutic benefits of ADT are well established, improving survival rates, reducing disease related symptoms and delaying cancer progression. ADT is used alone or in combination with chemotherapy and radiotherapy, or with newer hormonal agents such as abiraterone and enzalutamide. However, ADT is not without side effects including; decreased insulin sensitivity, changes in lipid profile, increased bone resorption, fatigue, loss of muscle mass, cognitive deficits and cardiovascular disease[1, 2].

The incidence of CVD and prostate cancer increases with age and CVD incidence and mortality is therefore high in men with prostate cancer[3, 4]. Based on findings of the Physician's Health Study, which was initiated in 1982, men aged between 70-89 years appear to be at the highest risk of having prostate cancer with concomitant CVD[5]. CVD is a common concomitant condition in patients with prostate cancer and was the cause of death in approximately 13$18 \%$ of patients in two large Phase 3 studies (European Organisation for Research and Treatment of Cancer 30,891 [ $n=985$ ] and South European Uroncological Group 9401 [ $n=626]$ ] [3, 4]. According to the European Association of Urology guidelines[6], CV mortality now even exceeds prostate cancer as the most common cause of death in patients with prostate cancer.

Certain CV comorbidities negatively influence prognosis in prostate cancer. A 12-year Danish population-based cohort study, looking at 30721 men with prostate cancer, demonstrated a $20 \%$ increase (Adjusted HR 1.20, 95\% Cl 1.12-1.30) in overall mortality in prostate cancer patients with a history of stroke, compared with those without ischemic heart disease (IHD) or stroke; pre-existing IHD had a lesser impact, but still increased mortality by $5 \%$ (Adjusted HR 1.05 95\% Cl 1.00-1.10)[7]. Furthermore, analysis of 10-year data from the Swedish National Prostate Cancer Register (PCBaSe) showed increased relative risks of nonfatal and fatal CVD among all prostate cancer patients, especially in those receiving ADT[8]. A meta-analysis of six large observational studies involving 295,407 participants (ADT treated and controls) also found that the significantly increased risk of CVD and CV mortality with a GnRH agonist alone or in combination with oral antiandrogen, but not with treatment with oral antiandrogen alone or with orchiectomy[9].

It appears that it is treatment with GnRH agonists specifically which has been associated with increased CV morbidity and mortality in several observational studies[10-13]. Among them, several population-based studies using data from the Surveillance, Epidemiology and End Results (SEER)-Medicare linked database demonstrated increased risk of incident diabetes, coronary heart disease, myocardial infarction (MI), sudden cardiac death[12, 14], and thromboembolic events[15] associated with GnRH agonist use in prostate cancer. This study adds further evidence to the still-unresolved question of whether ADT is associated with an increased risk of CVD. Men who had a surgical orchiectomy to lower their androgen levels had a $44 \%$ higher risk of non-fatal CVD compared with men with prostate cancer not treated with ADT[10]. It is thought that ADT may increase CVD risk in part by causing a distinct metabolic syndrome, increasing fat mass and reducing lean body mass, reducing insulin sensitivity and/or causing dyslipidaemia[16]. It should be noted that, while the increases in IHD rates may be partly due to changes in conventional risk factors induced by this distinct metabolic syndrome, there may be other factors affected by ADT that contribute to increases in IHD rates and sudden cardiac death, such as prolongation of the QTc interval, and cardiac toxicity[17] or direct hormonal effects on atherosclerotic plaque growth, rupture and thrombosis[18].

This review will summarise recent evidence on the cardiovascular risks associated with GnRH agonists and antagonists and provide advice on the assessment and mitigation of cardiovascular risk for prostate cancer patients in clinical practice.

\section{Methodology}

This review was conducted through a comprehensive search in PubMed and clinicaltrials.gov with the following key terms; "prostate cancer" AND "agonists" AND "antagonist" AND "cardiovascular" according to the recommendations in the PRISMA (Preferred Reporting Items for Systematic Review and Metaanalyses) statement. The initial search led to 106 publications, review articles and editorials were removed, with priority given to relevant clinical trials, metaanalyses and real-world evidence observational studies published in the last 10 years. In total 32 articles were retrieved and once duplicated were removed, 29 articles were reviewed as a result of the selection process (Supplementary Fig. 1).

\section{Randomised Controlled Trials (Rct'S)}


Prospective RCT's in patients with prostate cancer on ADT with major adverse cardiovascular events as endpoints are currently lacking[19]. The PRONOUNCE (NCT02663908) study is a RCT comparing the CV safety of degarelix verses leuprolide in prostate cancer patients with pre-defined cardiovascular disease[20]. The trial is currently in progress with 545 patients enrolled. Recruitment has now been stopped and the study is due for completion in 2021.

Cardiovascular morbidity among patients with prostate cancer and pre-existing $\mathrm{CV}$ disease receiving antagonists and agonists has been investigated in a smaller randomised controlled study $(\mathrm{N}=80)$ [21]. The aim of this study was to compare endothelial function and the number of major adverse cardiovascular and cerebrovascular events (MACCEs) defined as death, myocardial infarction, cerebrovascular event, heart catherization and stent insertion. Endothelial function, measured by an EndoPAT device did not differ between the treatment groups at 12 months (mean $\pm S D R H I 2.07 \pm 0.15$ vs $1.92 \pm 0.11$, $p=0.42$ ). This is likely due to the high proportion of patients with severe endothelial dysfunction at baseline. After 12 months, 8 (20\%) patients randomised to GnRH agonist had a MACCE compared to $1(3 \%)$ treated with the antagonist (ARR $=18.1 \%(95 \% \mathrm{Cl} 4.6-31.2)$, NNT = 6)[21]. High levels of N-terminal pro-B-type natriuretic peptide (NT-pro-BNP) and high-sensitivity troponin (hsTn) at baseline were associated with the development of new CV events in the agonist group but not in the antagonist group[22].

Recently, a phase III, randomised controlled trial compared the GnRH oral antagonist, Relugolix $(\mathrm{N}=622)$ with the LHRH agonist, Leuprorelin ( $\mathrm{N}=308)$. At baseline, more than $90 \%$ of all patients had at least one CV risk factor including lifestyle risk factors, diabetes, hypertension and a history of a major adverse cardiovascular event (MACE). $13.5 \%$ had a history of a MACE in the relugolix group vs $14.6 \%$ in the leuprolide group. Although not included as a primary or secondary endpoint, a pre-specified safety analysis showed the incidence of a MACE was $3.6 \%$ in the relugolix group and $17.8 \%$ in the leuprolide group (ARR = 14.2, NNT = 7)[23].

\section{Meta-analyses Of Randomised Controlled Trials}

Data pooled from 5 prospective, randomized trials $(n=1925)$ comparing the $\mathrm{GnRH}$ antagonist degarelix and LHRH agonists showed patients in the degarelix group had a lower risk for death after adjusting for baseline factors[24]. This difference in overall survival was unlikely to have been driven by prostate cancer deaths (only four patients died as a result of disease progression), but by cardiovascular events, with $51 \%$ of the deaths occurring in the $29 \%$ of patients with pre-existing cardiovascular disease[24]. This hypothesis was first investigated by analysing the data from 6 prospective, phase 3 randomised controlled trials $(\mathrm{N}=2328)$ comparing degarelix ( $\mathrm{N}=1491)$ with the agonists (either leuprolide, $\mathrm{n}=379$; or goserelin, $\mathrm{n}=458)$ [25]. Approximately 30\% of patients in both treatment groups had pre-existing CV disease. In the total patient population, there was a $40 \%$ relative risk reduction of a CV event or death in patients treated with degarelix compared with patients treated with a GnRH agonist (HR: $0.60 ; 95 \% \mathrm{Cl}, 0.41-0.87 ; \mathrm{p}=0.008)$. No differences were observed in the incidence of either death or $\mathrm{CV}$ events among the men who had no baseline CV disease. However, in those patients with pre-existing $\mathrm{CV}$ disease $(\mathrm{N}=708)$, there were significantly fewer cardiac events or deaths experienced by patients receiving a $\mathrm{GnRH}$ antagonist (6.5\%) compared with patients receiving GnRH agonists $(14.7 \%)(\mathrm{ARR}=8.2 \%, \mathrm{NNT}=12)[25]$.

Since this initial meta-analysis in 2014 serval other studies have been published. Abufaraj et al. carried out a meta-analysis from 8 clinical trials in 20 published studies that showed GnRH antagonists were associated with fewer cardiovascular events than GnRH agonists (RR:0.52, 95\% Cl 0.34-0.80)[26]. Sciarra et al. reported a similar outcome with analysis of 3 clinical trials showing treatment-related severe CV side effects including; prolonged QT interval, angina pectoris, atrial fibrillation, cardiac failure and $\mathrm{MI}$ ) reported in $1.6 \%$ of patients on degarelix and $3.6 \%$ of patients on $\mathrm{GnRH}$ agonists (OR-0.55, $95 \% \mathrm{Cl}$; $0.26-1.14, \mathrm{P}>0.1)$ [27]. One recent meta-analysis showed conflicting results with the incidence of CVD with GnRH agonists and antagonists equal (RR: 0.98 , $95 \% \mathrm{Cl}$ 0.94-1.02)[28]. However, the analysis in this study is not robust with a meta-analysis classed as a RCT leading to duplicate analyses and results should be interpreted with caution. The majority of results from clinical trials and meta-analyses demonstrate a recurring pattern by which ADT increases the risk of CV events, which appears to be driven by agonists[29].

\section{Real-world Observational Studies}

Real-world observational evidence has supported prospective and retrospective data. Analysis of prostate cancer patients from a UK primary care database ( $\mathrm{N}$ $=9,081$ ) showed that patients receiving degarelix had a higher baseline PSA than those initiating therapy with a GnRH agonist. In addition, more patients receiving degarelix had pre-existing CVD compared with patients receiving GnRH agonists. However, despite this difference in pre-existing CVD, in a post-hoc analysis, the relative risk of experiencing any cardiac event was lower with degarelix than all GnRH agonists $(6.9 \%$ vs $17.7 \% ; 0.39$ [0.191, 0.799]; $p=0.01)[30]$. Similar data was shown from Italian pharmacy and hospital databases. The incidence rate of CV events in agonist group was $8.80 / 100$ person-years vs $6.24 / 100$ person-years in the antagonist group $(P=0.002)$. The time to an event was beyond one year in both groups (mean years $\pm S D ;$ agonist $1.6 \pm 1.3$ vs antagonist 1.2 \pm 1.1 [31]. Lower cardiac events has also been reported from analysis of a pharmacovigilance data base (Vigibase) that collates adverse event reporting data from more than 130 countries[32]. Using disproportionality analysis, the authors found GnRH antagonists had no signal for any cardiac event other than heart failure (Reporting odds ratio (ROR) 1.91). The LHRH agonists showed a significant incidence of cardiac events (ROR 1.20) which was driven by MI (ROR 1.76) and heart failure (ROR 2.02). Time from initiation of therapy to CV event was over 1-year (mean 541.9 days, SD 909.6)[32].

In contrast, other real-world data studies have not demonstrated a clear CV risk benefit with the GnRH antagonist (Table 1). A French study analysed data from a health insurance database (35, 118 ADT users) which showed no significant association between GnRH antagonists and CV risk (adjusted HR [95\% confidence interval [CI] 1.2 [0.7-2.1])[33]. Combined androgen blockade was associated with an increased CV risk (adjusted HR [95\% confidence interval [CI] 1.6 [1.3-2.1]) and anti-androgen therapy was associated with a decreased risk of ischaemic events (adjusted HR [95\% confidence interval [CI] 0.6 [0.4-0.9]) compared with GnRH agonist therapy[33]. 
Table 1

ADT and cardiovascular outcomes from clinical studies

\begin{tabular}{|c|c|c|c|}
\hline Author & Type of Study & Patient numbers and study endpoints & CV outcomes \\
\hline \multirow{2}{*}{$\begin{array}{l}\text { Albertsen et } \\
\text { al. Eur Urol } \\
2014[25]\end{array}$} & \multirow{2}{*}{$\begin{array}{l}\text { Pooled, } \\
\text { retrospective study } \\
\text { of } 6 \text { prospective } \\
\text { trials }\end{array}$} & $N=2328$ & \multirow{2}{*}{$\begin{array}{l}\text { In patients with pre-existing CV disease at } \\
\text { baseline there was a } 56 \% \text { relative risk } \\
\text { reduction of a CV event or death in patients } \\
\text { treated with degarelix compared with } \\
\text { patients treated with a GnRH agonist (HR: } \\
0.44 ; 95 \% \mathrm{Cl}, 0.26-0.74 ; \mathrm{p}=0.002 \text { ). } \\
\text { Absolute risk reduction of a CV event or } \\
\text { death was } 8.2 \%, \mathrm{NNT}=12 \text {. }\end{array}$} \\
\hline & & $\begin{array}{l}\text { Number of deaths from any cause and the number of cardiac } \\
\text { events among all men receiving any form of ADT. Cardiac events } \\
\text { included; arterial embolic and thrombotic events, hemorrhagic or } \\
\text { ischemic cerebrovascular conditions, myocardial infarction or other } \\
\text { ischemic heart disease. }\end{array}$ & \\
\hline \multirow{2}{*}{$\begin{array}{l}\text { Scailteux et } \\
\text { al. Eur J } \\
\text { Cancer } \\
\text { 2017[33] }\end{array}$} & \multirow{2}{*}{$\begin{array}{l}\text { Retrospective } \\
\text { population-based } \\
\text { cohort study (RWE) }\end{array}$} & $N=35,118$ & \multirow{2}{*}{$\begin{array}{l}\text { No significant association between GnRH } \\
\text { antagonists and CV risk, although } \\
\text { combined androgen blockade was } \\
\text { associated with an increased risk and anti- } \\
\text { androgen therapy was associated with a } \\
\text { decreased risk of ischaemic events } \\
\text { compared with GnRH agonist therapy. }\end{array}$} \\
\hline & & $\begin{array}{l}\text { Occurrence of 'ischaemic } \\
\text { events' }\end{array}$ & \\
\hline $\begin{array}{l}\text { Abufaraj et } \\
\text { al. }\end{array}$ & \multirow[t]{2}{*}{ Meta-analyses } & $N=2,632$ & \multirow{2}{*}{$\begin{array}{l}\text { GnRH antagonist was associated with } \\
\text { fewer cardiovascular events (RR: } 0.52,95 \% \\
\text { Cl: } 0.34-0.80 \text { ) }\end{array}$} \\
\hline $\begin{array}{l}\text { Eur Urol } \\
2020[26]\end{array}$ & & $\begin{array}{l}\text { CV events; arterial embolic and throm- botic events, ischemic } \\
\text { cerebrovascular events, myocardial infarction, and other ischemic } \\
\text { heart disease. }\end{array}$ & \\
\hline \multirow{3}{*}{$\begin{array}{l}\text { Sciarra et al. } \\
\text { Medicine } \\
2016[27]\end{array}$} & \multirow[t]{3}{*}{ Meta-analyses } & $N=1719$ & \multirow{3}{*}{$\begin{array}{l}\text { Treatment-related severe cardiovascular } \\
\text { side effects } \\
\text { were reported in } 1.6 \% \text { and } 3.6 \% \text { of patients } \\
\text { in the degarelix and } \mathrm{GnRH} \text { agonists group, } \\
\text { respectively }(\mathrm{OR}=0.55,95 \% \mathrm{Cl}: 0.26-1.14 \text {, } \\
\mathrm{P}>0.1)\end{array}$} \\
\hline & & Treatment related severe cardiovascular side effects; QT & \\
\hline & & $\begin{array}{l}\text { interval increase, angina pectoris, atrial fibrillation, cardiac failure, } \\
\text { and myocardial ischemia }\end{array}$ & \\
\hline \multirow{2}{*}{$\begin{array}{l}\text { Ma et al. } \\
\text { Minerva } \\
\text { Urologica e } \\
\text { Nefrologica } \\
2020[28]\end{array}$} & \multirow[t]{2}{*}{ Meta-analyses } & $N=32,887$ & \multirow{2}{*}{$\begin{array}{l}\text { The results of meta-analysis showed that } \\
\text { compared with GnRH agonist, the incidents } \\
\text { of CVD was equal to GnRH antagonist } \\
\text { therapy for patient with PCa (RR } 0.98,95 \% \\
\text { Cl } 0.94-1.02 \text { ). }\end{array}$} \\
\hline & & CVD outcomes & \\
\hline \multirow{2}{*}{$\begin{array}{l}\text { Cardwell et } \\
\text { al. } \\
\text { Epidemiology } \\
2019[35]\end{array}$} & \multirow{2}{*}{$\begin{array}{l}\text { Retrospective } \\
\text { population-based } \\
\text { cohort study (RWE) }\end{array}$} & $N=20,216$ & \multirow{2}{*}{$\begin{array}{l}30 \% \text { increase in CV risk with ADT compared } \\
\text { with untreated patients; they report a } 30 \% \\
\text { increase in risk with GnRH agonists and a } \\
50 \% \text { increase in risk with degarelix }\end{array}$} \\
\hline & & $\begin{array}{l}\text { Cardiovascular events consisting of either death from } \\
\text { cardiovascular disease or hospitalization for cardiovascular } \\
\text { disease. CV disease type included acute myocardial infarction, } \\
\text { stroke, venous thromboembolism, heart failure, arrhythmia, and } \\
\text { other cardiovascular diseases. }\end{array}$ & \\
\hline \multirow{6}{*}{$\begin{array}{l}\text { Hupe et al. } \\
\text { Front Oncol } \\
2018[34]\end{array}$} & \multirow{6}{*}{$\begin{array}{l}\text { Retrospective } \\
\text { population-based } \\
\text { cohort study (RWE) } \\
\text { using a German } \\
\text { health insurance } \\
\text { database }\end{array}$} & $N=2,382$ & \multirow{6}{*}{$\begin{array}{l}\text { No significant differences in the incidence } \\
\text { of CVD or diabetes between GnRH agonists } \\
\text { or antagonists overall, although there was a } \\
\text { significant increase in hypertension in } \\
\text { patients receiving a GnRH agonist (16.4\%) } \\
\text { compared with those receiving a GnRH } \\
\text { antagonist }(6.9 \%, p=0.022)\end{array}$} \\
\hline & & To analyse real world & \\
\hline & & information on healthcare characteristics and treatment & \\
\hline & & patterns in patients with locally advanced or metastatic $\mathrm{PCa}$ & \\
\hline & & dependent on the prescribed GnRH agonist/antagonist agents & \\
\hline & & $(\mathrm{GnRHa})$ in the first 3 years after initiation. & \\
\hline \multirow{4}{*}{$\begin{array}{l}\text { Margel et al. } \\
\text { J Urol } \\
2020[21]\end{array}$} & \multirow{4}{*}{$\begin{array}{l}\text { Prospective, } \\
\text { randomised } \\
\text { controlled trial of } \\
80 \text { patients }\end{array}$} & $N=80$ & \multirow{4}{*}{$\begin{array}{l}\text { After } 12 \text { months, } 8(20 \%) \text { patients } \\
\text { randomised to GnR agonist had a MACCE } \\
\text { compared to } 1(3 \%) \text { treated with the } \\
\text { antagonist. Absolute risk reduction of a CV } \\
\text { event or death was } 18.1 \%(95 \% \mathrm{Cl} 4.6- \\
31.2) \text {, NNT }=6 \text {. }\end{array}$} \\
\hline & & $\begin{array}{l}\text { The study primary end point was to compare endothelial function } \\
\text { between the } 2 \text { arms. Cardiovascular events were a pre-defined } \\
\text { secondary outcome including; death, MI, CVA, a transient ischemic } \\
\text { attack, heart catheterization with or without intervention and } \\
\text { cardiac related hospitalization. MACCEs were }\end{array}$ & \\
\hline & & defined as death, MI, CVA and heart catheterization with & \\
\hline & & stent insertion & \\
\hline \multirow{2}{*}{$\begin{array}{l}\text { Davey et al. J } \\
\text { Urol 2020[64] }\end{array}$} & \multirow{2}{*}{$\begin{array}{l}\text { Retrospective } \\
\text { population-based } \\
\text { cohort study (RWE) } \\
\text { from UK primary } \\
\text { care database }\end{array}$} & $N=9.081$ & \multirow{2}{*}{$\begin{array}{l}\text { The relative risk of experiencing any CV } \\
\text { event was lower with degarelix than all } \\
\text { GnRH agonists }(6.9 \% \text { vs } 17.7 \%)(\text { ARR = } \\
10.8, \text { NNT }=9)\end{array}$} \\
\hline & & $\begin{array}{l}\text { The incidence of cardiac events following initiation of GnRH } \\
\text { antagonist (degarelix) or GnRH agonist (leuprorelin, goserelin or } \\
\text { triptorelin) as therapy in patients with prostate cancer. CV events } \\
\text { included; heart failure; myocardial infarction (MI); arrhythmia; } \\
\text { ischaemic heart disease. }\end{array}$ & \\
\hline
\end{tabular}




\begin{tabular}{|c|c|c|c|}
\hline Author & Type of Study & Patient numbers and study endpoints & CV outcomes \\
\hline $\begin{array}{l}\text { Perrone et al. } \\
\text { Therapeutics } \\
\text { and Clinical } \\
\text { Risk } \\
\text { Management } \\
\text { 2020[31] }\end{array}$ & $\begin{array}{l}\text { Retrospective } \\
\text { population-based } \\
\text { cohort study (RWE) }\end{array}$ & $\begin{array}{l}\mathrm{N}=9,785 \\
\text { The incidence rate of CV events } \\
\text { (acute myocardial infarction, ischemic heart diseases, } \\
\text { cerebrovascular diseases, cardiac dysrhythmias, heart failure, } \\
\text { atherosclerosis, aneurism, other CV-related conditions) was } \\
\text { calculated among patients not switching to androgen deprivation } \\
\text { therapy (ADT) in the } \\
\text { overall cohort and in a sub-cohort of patients without previous CV } \\
\text { events }\end{array}$ & $\begin{array}{l}\text { The incidence rate of CV events was } \\
\text { significantly higher in patients treated with } \\
\text { GnRH agonists rather than degarelix ( } 8.80 \\
\text { vs } 6.24 \text { per } 100 \text { person-year, p-value } 0.002) \text {, } \\
\text { with mean time to CV event beyond } 1 \text { year. }\end{array}$ \\
\hline $\begin{array}{l}\text { Cone et al. } \\
\text { BJU Int. } \\
2020[32]\end{array}$ & $\begin{array}{l}\text { Retrospective } \\
\text { Pharmacovigilance } \\
\text { database } \\
\text { (Vigibase) }\end{array}$ & $\begin{array}{l}\text { Cardiovascular reactions related to GnRH antagonist (degarelix) or } \\
\text { agonist (leuprolide, goserelin, triptorelin, histrelin) therapy for } \\
\text { prostate cancer. CV events included; myocardial infarction (MI), } \\
\text { heart failure (HF), carditis (cardiomyopathies, pericarditis, and } \\
\text { myocarditis), new valvular } \\
\text { dysfunction, and new arrythmias. }\end{array}$ & $\begin{array}{l}\text { Pharmacovigilance data showed increased } \\
\text { odds of cardiac events, driven by MI and } \\
\text { HF, for GnRH agonists but not for GnRH } \\
\text { antagonists. } 805(7.7 \%) \text { cardiac related } \\
\text { events were found for agonists and } 102 \\
(6.4 \%) \text { for antagonists. }\end{array}$ \\
\hline $\begin{array}{l}\text { Shore et al. } \\
\text { NEJM } \\
\text { 2020[23] }\end{array}$ & $\begin{array}{l}\text { Prospective, } \\
\text { Randomised } \\
\text { controlled trial } 934 \\
\text { patients }\end{array}$ & $\begin{array}{l}\mathrm{N}=930 \\
\text { The primary end point was the sustained castration rate, defined as } \\
\text { the cumulative probability of } \\
\text { testosterone suppression to less than } 50 \text { ng per deciliter during } \\
\text { receipt of trial treatment from } \\
\text { day } 29 \text { through } 48 \text { weeks. } \\
\text { Cardiovascular or cerebrovascular risk factors included } \\
\text { prespecified event terms in the MACE query and a manual search } \\
\text { of known risk factors, including hypertension; dyslipidemia; } \\
\text { diabetes; a history of myocardial infarction or cardiovascular } \\
\text { disease; a history of stroke, transient ischemic attack, or cerebral } \\
\text { haemorrhage; peripheral arterial disease; atrial fibrillation and other } \\
\text { arrhythmias; heart-valve disease; chronic obstructive pulmonary } \\
\text { disease; chronic kidney } \\
\text { disease; chronic liver disease; carotid-artery stenosis or occlusion; } \\
\text { venous thromboembolic events; and heart failure. }\end{array}$ & $\begin{array}{l}\text { In a prespecified analysis, in men with a } \\
\text { history of MACE, the incidence of major } \\
\text { adverse cardiovascular } \\
\text { events (MACE) was lower in the relugolix } \\
\text { group than in the leuprolide } \\
\text { group ( } 3.6 \% \text { vs. } 17.8 \% \text {, respectively). ARR = } \\
14.2, \text { NNT }=7\end{array}$ \\
\hline $\begin{array}{l}\text { George et al. } \\
\text { International } \\
\text { Journal of } \\
\text { Cancer } \\
2020[36]\end{array}$ & $\begin{array}{l}\text { Retrospective } \\
\text { population-based } \\
\text { cohort study (RWE) } \\
\text { using data from } 5 \\
\text { countries }\end{array}$ & $\begin{array}{l}\mathrm{N}=50,909 \\
\text { To combine real-world data from } 5 \text { countries to compare risk of } \\
\text { CVD between agonists and antagonists. CVD included; ischaemic } \\
\text { heart disease (IHD), acute myocardial infarction (AMI), arrhythmia, } \\
\text { heart failure (HF) and stroke. }\end{array}$ & $\begin{array}{l}\text { There was no difference in risk of any CVD } \\
\text { for men } \\
\text { on GnRH antagonists and agonists (HR: } \\
1.25 ; 95 \% \mathrm{Cl}: 0.96-1.61 ; 12: 64 \%) \text {. Men on } \\
\text { GnRH antagonists showed increased risk of } \\
\text { acute myocardial infarction (HR: } 1.62 ; 95 \% \\
\text { Cl: } 1.11-2.35 ; \text { I2: } 0 \% \text { ) and arrhythmia (HR: } \\
1.55 ; 95 \% \mathrm{Cl}: 1.11-2.15, \text { I2: } 17 \%) \\
\text { compared to GnRH agonists. }\end{array}$ \\
\hline
\end{tabular}

Retrospective analysis from a German claims database showed a higher proportion of patients treated with the antagonists had metastases compared to the agonist $(38 \%$ vs $30 \%, \mathrm{P}=0.002)$. In these patients, there were no significant differences in the incidence of CVD or diabetes between $\mathrm{GnRH}$ agonists or antagonists overall, although there was a significant increase in hypertension in patients receiving a $\mathrm{GnRH}$ agonist compared with those receiving a $\mathrm{GnRH}$ antagonist $(16.4 \%$ vs $6.9 \%, P=0.022)[34]$.

A recent registry study by Cardwell et al. in a cohort of $>22,000$ men with prostate cancer from the Scottish Cancer Registry who were prescribed ADTs between 2009 and 2015, found a 30\% increase in CV risk with ADT compared with untreated patients; they reported a 30\% increase in risk with GnRH agonists and a $50 \%$ increase in risk with degarelix[35].The authors state the association of higher CV risk with ADT compared with untreated patients was largely driven by $\mathrm{CV}$ events in $\mathrm{GnRH}$ agonist-treated patients; this may not allow for a conclusion to be drawn regarding the increase of CV risk with degarelix treatment, particularly given a risk of a Type 1 error (false positive) due to the small sample size.

Real-world data was analysed from 5 different countries (United Kingdom, Scotland, Belgium, Netherlands and France) to investigate CV risk in men with prostate cancer[36]. In total, 48, 757 men were treated with $\mathrm{GnRH}$ agonists and 2,144 on antagonists. There was no difference in risk of any CVD (ischaemic heart disease, acute myocardial infarction, arrhythmia, heart failure, and stroke) between GnRH antagonists and agonists (HR: 1.25; 95\% Cl: 0.96-1.61; I2: $64 \%$ ). Men on GnRH antagonists showed increased risk of acute myocardial infarction (HR: 1.62; 95\% Cl: 1.11-2.35; I2: 0\%) and arrhythmia (HR: 1.55; 95\% Cl: $1.11-2.15,12: 17 \%$ ) compared to GnRH agonists. The authors state that in such a large prospective cohort study it is difficult to fully homogenise study variables due to the varied data sources used. For example, the UK had no records for AMI because the data source used (THIN) was from a primary care setting. This heterogeneity in data sources may have affected the results of the study[36].

Real-world data observational studies provide a powerful insight into patient outcomes. However, they are limited by bias/confounding, differing sample sizes, missing data and the lack of randomisation and blinding. 
In summary, the available data indicate that GnRH agonists increase CV events and CVD and that the increase appears to be greatest in patients with preexisting CVD. While not definitive, some of the current evidence suggests that GnRH antagonists may be associated with lower rates of certain $\mathrm{CV}$ events vs agonists, particularly in patients with pre-existing CVD. We have reached this conclusion as the highest-grade evidence from randomised clinical trials comparing $\mathrm{GnRH}$ agonists verses antagonists is uniform in finding lower $\mathrm{CV}$ event rates with $\mathrm{GnRH}$ antagonists. Furthermore, although heterogeneous, the data from real-world observational studies does not seem to negate this view.

\section{Potential Mechanisms Underlying A Differential Cv Effect For Gnrh Agonists And Antagonists}

There are two potential mechanisms speculated to underlie the difference in $\mathrm{CV}$ risk between $\mathrm{GnRH}$ antagonists and agonists. The first centres on differential effects of the two agents on T lymphocyte activation and destabilisation of atherosclerotic plaques and the second focuses on the role of FSH (Fig. 1)

(Table 2)[1, 37].

Table 2

ADT and cardiovascular outcomes from pre-clinical and in vitro studies

\begin{tabular}{|c|c|c|c|}
\hline Authors & Animal model & $\begin{array}{l}\text { Patient numbers and study } \\
\text { endpoints/objectives }\end{array}$ & CV outcomes \\
\hline $\begin{array}{l}\text { Hopmans SN, et } \\
\text { al. Urol Oncol } \\
\text { 2014[44] }\end{array}$ & $\begin{array}{l}\text { Low-density } \\
\text { lipoprotein receptor } \\
\text { knockout mice ( LDL } \\
\text { KO) }\end{array}$ & $\begin{array}{l}\mathrm{N}=9-13 / \text { group } \\
\text { To investigate the effects of bilateral } \\
\text { orchiectomy, } \\
\text { GnRH agonist, and GnRH antagonist } \\
\text { on the development of adiposity, } \\
\text { dysglycemia, and atherosclerosis in a } \\
\text { mouse model. }\end{array}$ & $\begin{array}{l}\text { Degarelix treated mice gained less visceral fat, had improved } \\
\text { glucose tolerance and had significantly smaller necrotic plaque } \\
\text { areas compared with leuprolide and orchiectomised mice. }\end{array}$ \\
\hline $\begin{array}{l}\text { Knutsson A, et al. } \\
\text { Sci Rep 2016[43] }\end{array}$ & $\begin{array}{l}\text { Male ApoE-/- mice } \\
\text { A shear stress } \\
\text { modifier was used to } \\
\text { produce both } \\
\text { advanced } \\
\text { and more stable } \\
\text { plaques in the carotid } \\
\text { artery. }\end{array}$ & $\begin{array}{l}\mathrm{N}=6-9 / \text { group } \\
\text { To investigate the } \\
\text { effects of degarelix and leuprolide on } \\
\text { atherosclerotic plaques in high-fat } \\
\text { fed ApoE-/- mice. }\end{array}$ & $\begin{array}{l}\text { Leuprolide treated mice had increased areas of necrosis observed } \\
\text { in stable plaques and greater inflammation vs degarelix treated } \\
\text { mice (demonstrated by greater macrophage accumulation within } \\
\text { the plaques). }\end{array}$ \\
\hline $\begin{array}{l}\text { Chen et al. J. } \\
\text { Clinical } \\
\text { Endocrinology } \\
\text { and Metabolism } \\
1999[38]\end{array}$ & $\begin{array}{l}\text { RT-PCR was used to } \\
\text { analyse peripheral } \\
\text { blood mononuclear } \\
\text { cells (PBMCs) }\end{array}$ & $\begin{array}{l}\text { To identify the presence of } \mathrm{GnRH} \\
\text { and GnRH receptors in human } \\
\text { peripheral blood mononuclear cells }\end{array}$ & $\begin{array}{l}\text { GnRH receptors are also expressed in human peripheral blood } \\
\text { mononuclear cells. The endogenous production of GnRH by } \\
\text { lymphocytes may act as an autocrine or paracrine factor to } \\
\text { regulate immune functions. }\end{array}$ \\
\hline $\begin{array}{l}\text { Tanriverdi et al. } \\
2005 \text { Clinical and } \\
\text { Experimental } \\
\text { Immunology[40] }\end{array}$ & $\begin{array}{l}\text { Peripheral blood } \\
\text { mononuclear cells } \\
\text { (PBMCs) isolated } \\
\text { from healthy males }\end{array}$ & $\begin{array}{l}\mathrm{N}=6 \\
\text { To investigate the inflammatory } \\
\text { effects of } \mathrm{GnRH}-\mathrm{I} \text { and/or GnRH-II on } \\
\text { human } \mathrm{PMBC} \text { proliferation } \\
\text { in males }\end{array}$ & $\begin{array}{l}\text { GnRH-I and GnRH-II receptors increased the expression of IL-2 } \\
\text { mRNA in a dose dependent manner which was associated with } \\
\text { increased proliferation of PBMC's. }\end{array}$ \\
\hline
\end{tabular}

GnRH receptors are expressed are on T lymphocytes which are stimulated by $\mathrm{GnRH}$ agonists[38]. This triggers an inflammatory cascade, stimulating proliferation of T cells and production of pro-inflammatory cytokines. Activated macrophages produce matrix metalloproteinases (MMP's) which degrade the fibrotic cap within vulnerable plaques[25,38-41]. This increases the risk of atherosclerotic plaque rupture[37], and disruption of atheromatous plaques are a frequent cause of fatal coronary thrombi[42].Unlike GnRH agonists, GnRH antagonists lack the ability to activate T lymphocytes, thus maintaining plaque stability (Fig. 1)[37]. Currently, research of this mechanism remains in pre-clinical studies. In ApoE(-/-) mice, treatment with the GnRH agonist leuprolide, but not the $\mathrm{GnRH}$ receptor antagonist degarelix, induced atherosclerotic plaque instability[43].

A parallel hypothesis centres around the role of FSH. Animal studies have implicated FSH in cardiovascular morbidity with mouse models showing dysfunctional fat increased in an FSH dependent manner (Table 2)[44]. Further, antagonist treated mice had significantly lower levels of FSH, a lower percentage of adipose tissue and had half the number of atherosclerotic plaques and less inflammation compared with agonist or orchiectomy[44]. FSH has also been shown to stimulate pro-inflammatory cytokine release from immune cells, providing another mechanism by which plaque stability may be disrupted (Fig. 1)[1]. Clinical data has reflected some of these findings with clinical trial data showing FSH is supressed to a greater extent with antagonists compared to agonists. Additionally, in a prospective study, patients with less than a $60 \%$ decrease in FSH levels during the first three months of treatment had a higher risk of developing a cardiovascular event ( $40 \%$ vs $10 \%, p=0.005$ )[45]. Further clinical research is needed to explore these mechanisms and to determine whether preclinical findings and hypotheses translate into differences in risk in a clinical setting.

\section{Androgen Deprivation Therapy And Diabetes}

Given the association of type 2 diabetes mellitus with CVD, CV morbidity and mortality[46], data assessing a potential impact of ADT on the development of diabetes are also of interest in this context. A meta-analysis of eight studies assessing diabetes-related outcomes in patients with prostate cancer who received ADT compared with ADT-naïve patients showed that the pooled incidence of diabetes was $39 \%$ higher in patients receiving ADT compared with 
control groups (risk ratio [RR] 1.39, 95\% confidence interval [Cl]; 1.27-1.53; $\mathrm{p}<0.001$ ). In subgroup analyses, diabetes was found to be associated with GnRH agonists (RR 1.45, 95\% Cl 1.36-1.54; p < 0.001), GnRH agonists + antiandrogens (RR 1.40,95\% Cl 1.01-1.93; $\mathrm{p}=0.04)$ and orchiectomy (RR $1.34,95 \% \mathrm{Cl}$ $1.20-1.50 ; p<0.001)$, but not with antiandrogens alone (RR 1.33, 95\% Cl 0.75-2.36; $p=0.33$ ). Diabetes risk appeared to increase with the length of $A D T$ treatment ( $\leq 6$ months: RR 1.29, 95\% Cl 1.12-1.49, $p=0.0004$; $>6$ months: RR 1.43, 95\% Cl 1.22-1.68, $p<0.001)[47]$.

\section{Assessment And Mitigation Of Cv Risk In Clinical Practice}

A central component of any risk reduction strategy is education to increase awareness among prostate cancer patients of signs and symptoms of CVD and modifiable CV risk factors. In the absence of formal guidelines for the prevention and management of CVD in prostate cancer patients receiving ADT, strategies can be put in place to control for CV risk factors in these patients - the ABCDE paradigm (Awareness and Aspirin, Blood Pressure, Cholesterol and Cigarette, Diet and Diabetes and Exercise) developed by Bhatia and colleagues is one example[48].

The INTERHEART study showed that nine modifiable risk factors were significantly associated with acute MI in both men and women and taken together these factors accounted for more than $90 \%$ of the population-attributable risk: hypertension, diabetes, physical activity, alcohol use, abnormal lipids, smoking, abdominal obesity, unhealthy diet, and psychosocial stress[49]. This study confirms the importance of multiple risk factor intervention to reduce the overall risk of cardiovascular events.

The group at highest risk of CV events are those who have already had a vascular event, followed by those with the largest number of risk factors (age, diabetes, and smoking)[48]. The risk of those without pre-existing CVD and risk factors can by formally calculated by QRISK. Thus, screening for known and undiagnosed metabolic and CV risk factors and risk calculation QRISK or JBS3 is key to risk mitigation, enabling stratification of prostate cancer patients according to the level of risk (e.g. 'CV history/high CV risk' vs 'no history/low risk')[50]. The use of such tools are recommended in a recent publication by the International Cardio-oncology society for patients receiving ADT[51]. The Canadian Urological Association have recently published guidelines on the screening and management of CV health in prostate cancer patients with simple "STAMP" questions (Stroke, Transient Ischaemic attack, Abdominal Aortic Aneurysm, Myocardial Infarction, Peripheral arterial disease) and the recommendation for every patient to collect routine medical history; perform a physical examination; determine the lipid profile, measure HbA1c, uric acid, serum electrolytes and creatinine; and complete blood count (CBC) and electrocardiogram (ECG)[52].

Ongoing monitoring and treatment of CV risk factors is important. For example, treatment with GnRH agonists can lead to diabetes (due to the development of insulin resistance or altered insulin sensitivity), obesity, and other metabolic changes, including changes in lipid levels, which can exacerbate atherosclerotic diseases[47, 53-57].

In addition, key changes in patients' habits should be encouraged, the goal being to maintain a healthy lifestyle. Advice should be given regarding smoking cessation, healthy diet, weight control and daily exercise[48]. However, patients with CV symptoms (which should be asked for) may also need targeted investigation and treatment by a cardiologist.

Pharmacological interventions include angiotensin converting enzyme inhibitors, which are the recommended first choice agents for hypertension due to mortality-risk reduction in patients with diabetes and CVD, and possibly improved outcomes in cancer patients, including those with prostate cancer[48, 58]. Hyperlipidaemia should be treated with high intensity statin therapy, especially in the presence of diabetes or CVD (Box 1)[48]. While metformin has been the preferred agent for treatment of diabetes in this population due to its favourable effects on the metabolic syndrome[48], newer diabetes treatments include dipeptidyl peptidase-4 inhibitors (DPP-4Is), glucagon-like peptide-1 receptor agonists (GLP-1RAs), and sodium-glucose co-transporter 2 inhibitors (SGLT-2Is; Box 1). In large cardiovascular outcome trials, which have been a requirement by the US Food and Drug Administration since 2008, GLP-1RAs and SGLT-2Is have demonstrated $\mathrm{CV}$ benefits in addition to improving glycaemic control, and empagliflozin and canagliflozin (both SGLT-2Is) demonstrated significant reductions in major adverse cardiovascular events. Guidelines from the American Diabetes Association (ADA), the European Association for the Study of Diabetes (EASD) and the American College of Cardiology recommend SGLT2ls or GLP-1RAs in patients with type 2 diabetes and additional risk factors for CVD, since these agents have been shown to improve cardiovascular outcomes over 2-5 years[59,60]. The 2019 update of the 2018 ADA and EASD guidelines specifies that the decision to treat high-risk individuals with these agents should now be considered independently of baseline $\mathrm{HbA} 1 \mathrm{c}$ or individualised HbA1c target[61]. On the other hand, DPP-4Is only showed low to moderate glycaemic efficacy and no CV or renal benefit, with some agents in this class having been associated with an increase in heart failure[62].

In prostate cancer patients, appropriate ADT should be undertaken, with particular caution in patients with pre-existing CVD and/or > 10\% CVD 10-year risk (assessed using QRISK2), which is the treatment threshold for primary prevention of CVD as per NICE guidelines[63]. A checklist for urologists, oncologists and clinical nurse specialists may prove useful, encompassing CV history, concomitant medication, lifestyle approach, ADT, risk of recurrence, and tumour aggressiveness. Figure 2 provides a template CV risk assessment tool, to help risk stratify patients and consider ADT modality accordingly.

\section{Summary}

This review suggests that while not definitive, most of the available data suggest that GnRH agonist treatment increases CVD and diabetes risk and that the negative effects may be greatest in patients with pre-existing CVD. It also appears that GnRH antagonist therapy is associated with lower rates of new cardiovascular events than in those with pre-existing CVD treated. Given all the data that is currently available, identification of baseline CV risk factors may be key to risk mitigation in patients with prostate cancer receiving ADT. In addition to choosing the appropriate therapy for prostate cancer, appropriate lifestyle and other pharmacological interventions should be recommended, and CV risk factors should be monitored long-term.

\section{Declarations}




\section{Consent for publication N/A}

Availability of data and materials The datasets generated during and/or analysed during the current study are available in the PubMed repository. Search results can be found at the following link: file:///C:/Users/clee/OneDrive\%20-

\%20Ferring\%20Pharmaceuticals/Firmagon/CV\%20risk\%20review/106\%20((prostate\%20cancer)\%20AND\%20(cardiovascular))\%20AND\%20(agonist)\%20AND\%

\%20Search\%20Results\%20-\%20PubMed.html

Competing Interests PD reports personal fees from Ferring pharmaceutical company during the conduct of the study. KA reports no conflicts of interests or disclosures.

Funding Medical writing support was funded by Ferring Pharmaceuticals Ltd (UK) and provided by Hannah Fleetwood and Kate Booth, on behalf of Bioscript Science, Macclesfield, UK.

Author Contributions PD and KA made a significant contribution to the concept, structure, content, preparation, writing and review of the manuscript and agree to its publication. Medical writing support were funded by Ferring Pharmaceuticals Ltd (UK).

\section{Acknowledgements N/A}

\section{References}

1. Crawford ED, Schally A V., Pinthus JH, Block NL, Rick FG, Garnick MB, et al. The potential role of follicle-stimulating hormone in the cardiovascular, metabolic, skeletal, and cognitive effects associated with androgen deprivation therapy. Urol Oncol Semin Orig Investig. 2017;35:183-91. doi:10.1016/j.urolonc.2017.01.025.

2. Plummer C, Collins P, Rosario DJ, Kirby M, Jain S, Davey P, et al. Managing cardiovascular risk in high-risk prostate cancer. Trends Urol Men's Heal. 2017;8:13-8.

3. Studer UE, Whelan P, Albrecht W, Casselman J, De Reijke T, Hauri D, et al. Immediate or deferred androgen deprivation for patients with prostate cancer not suitable for local treatment with curative intent: European organisation for research and treatment of cancer (EORTC) trial 30891. J Clin Oncol. 2006;24:1868-76.

4. Calais da Silva FEC, Bono A V., Whelan P, Brausi M, Marques Queimadelos A, Martin JAP, et al. Intermittent Androgen Deprivation for Locally Advanced and Metastatic Prostate Cancer: Results from a Randomised Phase 3 Study of the South European Uroncological Group. Eur Urol. 2009;55:1269-77.

5. Driver JA, Djoussé L, Logroscino G, Gaziano JM, Kurth T. Incidence of cardiovascular disease and cancer in advanced age: Prospective cohort study. Bmj. 2008;337:1400-3.

6. Mottet N, Bergh RCN Van Den, Vice-chair PC, Santis M De, Gillessen S, Govorov A, et al. EAU-ESUR-ESTRO-SIOG Guidelines on Prostate Cancer/ Guias Europeas. Eur Assoc Urol 2018. 2018;:1-145. http://uroweb.org/guidelines/compilations-of-all-guidelines/.

7. Jespersen CG, Nørgaard M, Bjerklund Johansen TE, Søgaard M, Borre M. The influence of cardiovascular morbidity on the prognosis in prostate cancer. Experience from a 12-year nationwide Danish population-based cohort study. BMC Cancer. 2011;11:519. doi:10.1186/1471-2407-11-519.

8. Van Hemelrijck M, Garmo H, Holmberg L, Ingelsson E, Bratt O, Bill-Axelson A, et al. Absolute and relative risk of cardiovascular disease in men with prostate cancer: Results from the population-based PCBaSe Sweden. J Clin Oncol. 2010;28:3448-56.

9. Zhao J, Zhu S, Sun L, Meng F, Zhao L, Zhao Y, et al. Androgen deprivation therapy for prostate cancer is associated with cardiovascular morbidity and mortality: A meta-analysis of population-based observational studies. PLoS One. 2014;9.

10. O'Farrell S, Garmo H, Holmberg L, Adolfsson J, Stattin P, Van Hemelrijck M. Risk and timing of cardiovascular disease after androgen-deprivation therapy in men with prostate cancer. J Clin Oncol. 2015;33:1243-51.

11. Bosco C, Bosnyak Z, Malmberg A, Adolfsson J, Keating NL, Van Hemelrijck M. Quantifying Observational Evidence for Risk of Fatal and Nonfatal Cardiovascular Disease Following Androgen Deprivation Therapy for Prostate Cancer: A Meta-analysis. Eur Urol. 2015;68:386-96. doi:10.1016/j.eururo.2014.11.039.

12. Gandaglia G, Sun M, Popa I, Schiffmann J, Abdollah F, Trinh QD, et al. The impact of androgen-deprivation therapy (ADT) on the risk of cardiovascular (CV) events in patients with non-metastatic prostate cancer: A population-based study. BJU Int. 2014;114:E82-9.

13. Nguyen PL, Je Y, Schutz FAB, Hoffman KE, Hu JC, Beckman JA, et al. Association of Androgen Deprivation Therapy With Cardiovascular Death in Patients With Prostate Cancer. JAMA - J Am Med Assoc. 2011;306:2359-66.

14. Keating NL, O'Malley AJ, Freedland SJ, Smith MR. Diabetes and cardiovascular disease during androgen deprivation therapy: Observational study of veterans with prostate cancer. J Natl Cancer Inst. 2010;102:39-46.

15. Ehdaie B, Atoria LC, Gupta A, Feifer A, Lowrance TW, Morris MJ, et al. Androgen Deprivation and Thromboembolic Events in Men with Prostate Cancer. Cancer. 2012;118:3397-406.

16. Levine GN, D'Aamico A V., Berger P, Clark PE, Eckel RH, Keating NL, et al. Androgen-deprivation therapy in prostate cancer and cardiovascular risk: A science advisory from the American heart association, American cancer society, and American urological association. Circulation. 2010;121:833-40.

17. Gagliano-Jucá T, Travison TG, Kantoff PW, Nguyen PL, Taplin ME, Kibel AS, et al. Androgen deprivation therapy is associated with prolongation of QTc interval inmen with prostate cancer. J Endocr Soc. 2018;2:485-96. 
18. Zareba P, Duivenvoorden W, Leong DP, Pinthus JH. Androgen deprivation therapy and cardiovascular disease: What is the linking mechanism? Ther Adv Urol. 2016;8:118-29.

19. Higano CS. Cardiovascular Disease and Androgen Axis- Targeted Drugs for Prostate Cancer. N Engl J Med. 2020;382:2257-9.

20. Melloni C, Slovin SF, Blemings A, Goodman SG, Evans CP, Nilsson J, et al. Cardiovascular Safety of Degarelix Versus Leuprolide for Advanced Prostate Cancer. JACC CardioOncology. 2020;2:70-81.

21. Margel D, Peer A, Ber Y, Shavit-Grievink L, Tabachnik T, Sela S, et al. Cardiovascular Morbidity in a Randomized Trial Comparing GnRH Agonist and GnRH Antagonist among Patients with Advanced Prostate Cancer and Preexisting Cardiovascular Disease. J Urol. 2019;202:1199-207.

22. Margel D, Ber Y, Peer A, Shavit-Grievink L, Pinthus JH, Witberg G, et al. Cardiac biomarkers in patients with prostate cancer and cardiovascular disease receiving gonadotrophin releasing hormone agonist vs antagonist. Prostate Cancer Prostatic Dis. 2020; Cv. doi:10.1038/s41391-020-0264-9.

23. Shore ND, Saad F, Cookson MS, George DJ, Saltzstein DR, Tutrone R, et al. Oral relugolix for androgen-deprivation therapy in advanced prostate cancer. N Engl J Med. 2020;382:2187-96.

24. Klotz L, Miller K, Crawford ED, Shore N, Tombal B, Karup C, et al. Disease control outcomes from analysis of pooled individual patient data from five comparative randomised clinical trials of degarelix versus luteinising hormone-releasing hormone agonists. Eur Urol. 2014;66:1101-8. doi:10.1016/j.eururo.2013.12.063.

25. Albertsen PC, Klotz L, Tombal B, Grady J, Olesen TK, Nilsson J. Cardiovascular morbidity associated with gonadotropin releasing hormone agonists and an antagonist. Eur Urol. 2014;65:565-73. doi:10.1016/j.eururo.2013.10.032.

26. Abufaraj M, Iwata T, Kimura S, Haddad A, Al-Ani H, Abusubaih L, et al. Differential Impact of Gonadotropin-releasing Hormone Antagonist Versus Agonist on Clinical Safety and Oncologic Outcomes on Patients with Metastatic Prostate Cancer: A Meta-analysis of Randomized Controlled Trials. Eur Urol. 2020;:1-10. doi:10.1016/j.eururo.2020.06.002.

27. Sciarra A, Fasulo A, Ciardi A, Petrangeli E, Gentilucci A, Maggi M, et al. A meta-analysis and systematic review of randomized controlled trials with degarelix versus gonadotropin-releasing hormone agonists for advanced prostate cancer. Med (United States). 2016;95.

28. Ma C, Abeysekera IR, Wenbin X, Wang Y, Peng J, Li H. Comparing the risk of cardiovascular disease following GnRH agonist and GnRH antagonist therapy for patient with prostate cancer: a systematic review and meta-analysis. Minerva Urol Nefrol. 2020.

29. Hu JR, Duncan MS, Morgans AK, Brown JD, Meijers WC, Freiberg MS, et al. Cardiovascular effects of androgen deprivation therapy in prostate cancer: Contemporary meta-analyses. Arterioscler Thromb Vasc Biol. 2019; March:E55-64.

30. Davey P, Kirby MG. Cardiovascular risk profiles of GnRH agonists and antagonists: real - world analysis from UK general practice. World J Urol. 2020; Cv. doi:10.1007/s00345-020-03433-3.

31. Perrone V, Esposti LD, Giacomini E, Veronesi C, Blini V, Oderda M. Cardiovascular risk profile in prostate cancer patients treated with gnrh agonists versus antagonists: An italian real-world analysis. Ther Clin Risk Manag. 2020;16:393-401.

32. Cone EB, Marchese M, Reese SW, Sun M, Nabi J, Kilbridge K, et al. Lower odds of cardiac events for gonadotrophin-releasing hormone antagonists versus agonists. BJU Int. 2020;126:9-10.

33. Scailteux LM, Vincendeau S, Balusson F, Leclercq C, Happe A, Le Nautout B, et al. Androgen deprivation therapy and cardiovascular risk: No meaningful difference between GnRH antagonist and agonists-a nationwide population-based cohort study based on 2010-2013 French Health Insurance data. Eur J Cancer. 2017;77:99-108.

34. Hupe MC, Hammerer P, Ketz M, Kossack N, Colling C, Merseburger AS. Retrospective analysis of patients with prostate cancer initiating GnRH agonists/antagonists therapy using a German claims database: Epidemiological and patient outcomes. Front Oncol. 2018;8 NOV.

35. Cardwell CR, O'Sullivan JM, Jain S, Harbinson MT, Cook MB, Hicks BM, et al. The risk of cardiovascular disease in prostate cancer patients receiving androgen deprivation therapies. Epidemiology. 2020;:432-40.

36. George G, Garmo H, Scailteux LM, Balusson F, De Coster G, De Schutter H, et al. Risk of cardiovascular disease following gonadotropin-releasing hormone agonists vs antagonists in prostate cancer: Real-world evidence from five databases. Int J Cancer. 2020.

37. Rosario DJ, Davey P, Green J, Greene D, Turner B, Payne H, et al. The role of gonadotrophin-releasing hormone antagonists in the treatment of patients with advanced hormone-dependent prostate cancer in the UK. World J Urol. 2016;34:1601-9.

38. Chen H, Jeung E, Stephenson M, Leung PCK. Human Peripheral Blood Mononuclear Cells Express Gonadotropin-Releasing Hormone (GnRH), GnRH Receptor, and Interleukin-2 Receptor Chain Messenger Ribonucleic Acids That Are Regulated by GnRH in Vitro. Endocrinol Metab. 1999;84:743-50.

39. Libby P. Molecular and cellular mechanisms of the thrombotic complications of atherosclerosis. J Lipid Res. 2009;50 SUPPL.:352-7.

40. Tanriverdi F, Gonzalez-Martinez D, Hu Y, Kelestimur F, Bouloux PMG. GnRH-I and GnRH-II have differential modulatory effects on human peripheral blood mononuclear cell proliferation and interleukin-2 receptor $Y$-chain mRNA expression in healthy males. Clin Exp Immunol. 2005;142:103-10.

41. Grasso G. The effect of LHRH and TRH on human interferon-gamma production in vivo and in vitro. $2014 ; 62$.

42. Bentzon JF, Otsuka F, Virmani R, Falk E. Mechanisms of plaque formation and rupture. Circ Res. 2014;114:1852-66.

43. Knutsson A, Hsiung S, Celik S, Rattik S, Mattisson IY, Wigren M, et al. Treatment with a GnRH receptor agonist, but not the GnRH receptor antagonist degarelix, induces atherosclerotic plaque instability in ApoE-/- mice. Sci Rep. 2016;6 September 2015:1-10. doi:10.1038/srep26220.

44. Hopmans SN, Duivenvoorden WCM, Werstuck GH, Klotz L, Pinthus JH. GnRH antagonist associates with less adiposity and reduced characteristics of metabolic syndrome and atherosclerosis compared with orchiectomy and GnRH agonist in a preclinical mouse. Urol Oncol Semin Orig Investig. 2014;32:1126-34. doi:10.1016/j.urolonc.2014.06.018.

45. Margel D, Pe'er A, Ber Y, Shaparberg M, Sela S, Ozalvo R, et al. Mp52-17 Cardiovascular Events and Biomarkers in a Randomized Trial Comparing Lhrh Agonist and Antagonist Among Patients With Advanced Prostate Cancer. J Urol. 2018;199:e702. doi:10.1016/j.juro.2018.02.1668.

Page 9/12 
46. Martín-Timón I. Type 2 diabetes and cardiovascular disease: Have all risk factors the same strength? World J Diabetes. $2014 ; 5: 444$.

47. Wang H, Sun X, Zhao L, Chen X, Zhao J. Androgen deprivation therapy is associated with diabetes: Evidence from meta-analysis. J Diabetes Investig. 2016;7:629-36.

48. Bhatia N, Santos M, Jones LW, Beckman JA, Penson DF, Morgans AK, et al. Cardiovascular Effects of Androgen Deprivation Therapy for the Treatment of Prostate Cancer. Circulation. 2016;133:537-41.

49. Anand SS, Islam S, Rosengren A, Franzosi MG, Steyn K, Yusufali AH, et al. Risk factors for myocardial infarction in women and men: Insights from the INTERHEART study. Eur Heart J. 2008;29:932-40.

50. Hippisley-Cox J, Coupland C, Brindle P. Development and validation of QRISK3 risk prediction algorithms to estimate future risk of cardiovascular disease: Prospective cohort study. BMJ. 2017;357 May:1-21. doi:10.1136/bmj.j2099.

51. Lyon AR, Dent S, Stanway S, Earl H, Brezden-Masley C, Cohen-Solal A, et al. Baseline cardiovascular risk assessment in cancer patients scheduled to receive cardiotoxic cancer therapies: a position statement and new risk assessment tools from the Cardio-Oncology Study Group of the Heart Failure Association of the European Society. Eur J Heart Fail. 2020;22:1945-60.

52. Kenk M, Grégoire JC, Coté MA, Connelly KA, Davis MK, Dresser G, et al. Optimizing screening and management of cardiovascular health in prostate cancer. Can Urol Assoc J. 2020;14:1-18.

53. Smith MR, Lee H, Nathan DM. Insulin sensitivity during combined androgen blockade for prostate cancer. J Clin Endocrinol Metab. 2006;91:1305-8.

54. Basaria S, Muller DC, Carducci MA, Egan J, Dobs AS. Hyperglycemia and insulin resistance in men with prostate carcinoma who receive androgendeprivation therapy. Cancer. 2006;106:581-8.

55. Lage MJ, Barber BL, Markus RA. Association Between Androgen-Deprivation Therapy and Incidence of Diabetes Among Males with Prostate Cancer. Urology. 2007;70:1104-8.

56. Braga-Basaria M, Dobs AS, Muller DC, Carducci MA, John M, Egan J, et al. Metabolic syndrome in men with prostate cancer undergoing long-term androgen-deprivation therapy. J Clin Oncol. 2006;24:3979-83.

57. Smith MR. Changes in fat and lean body mass during androgen-deprivation therapy for prostate cancer. Urology. 2004;63:742-5.

58. Mc Menamin ÚC, Murray LJ, Cantwell MM, Hughes CM. Angiotensin-converting enzyme inhibitors and angiotensin receptor blockers in cancer progression and survival: A systematic review. Cancer Causes Control. 2012;23:221-30.

59. Davies MJ, D'Alessio DA, Fradkin J, Kernan WN, Mathieu C, Mingrone G, et al. Management of hyperglycemia in type 2 diabetes, 2018. A consensus report by the American Diabetes Association (ADA) and the european association for the study of diabetes (EASD). Diabetes Care. 2018;41:2669-701.

60. Arnett DK, Blumenthal RS, Albert MA, Buroker AB, Goldberger ZD, Hahn EJ, et al. 2019 ACC/AHA Guideline on the Primary Prevention of Cardiovascular Disease: Executive Summary: A Report of the American College of Cardiology/American Heart Association Task Force on Clinical Practice Guidelines. J Am Coll Cardiol. 2019;74:1376-414.

61. Buse JB, Wexler DJ, Tsapas A, Rossing P, Mingrone G, Mathieu C, et al. 2019 update to: Management of hyperglycaemia in type 2 diabetes, 2018. A consensus report by the American Diabetes Association (ADA) and the European Association for the Study of diabetes (EASD) (Diabetologia, (2020), 63, 2, (221-228), 10.1. Diabetologia. 2020;63:1667.

62. Cefalu WT, Kaul S, Gerstein HC, Holman RR, Zinman B, Skyler JS, et al. Cardiovascular outcomes trials in type 2 diabetes: Where Do We Go From Here? Ref lections From a Diabetes Care Editors' Expert Forum. Diabetes Care. 2018;41:14-31.

63. Https://1-Recommendations. NICE (2016) Cardiovascular disease: risk assessment and reduction, including lipid modification.

64. Davey P, Kirby M. Cardiovascular risk profiles of GnRH agonists and antagonists: real - world analysis from UK general practice. World J Urol. 2020;Accepted $n$.

\section{Figures}

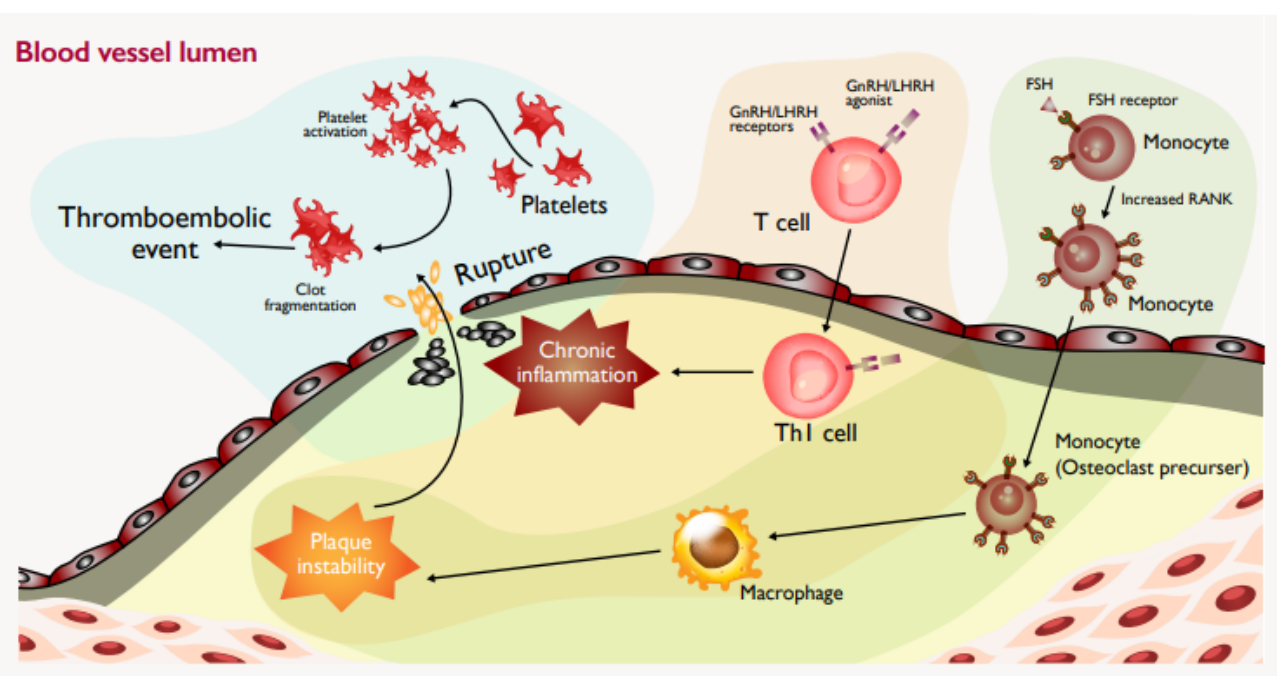

Page $10 / 12$ 
Figure 1

Proposed mechanism of differing CV risk between antagonists and agonists. Adapted from Crawford et al. 2017

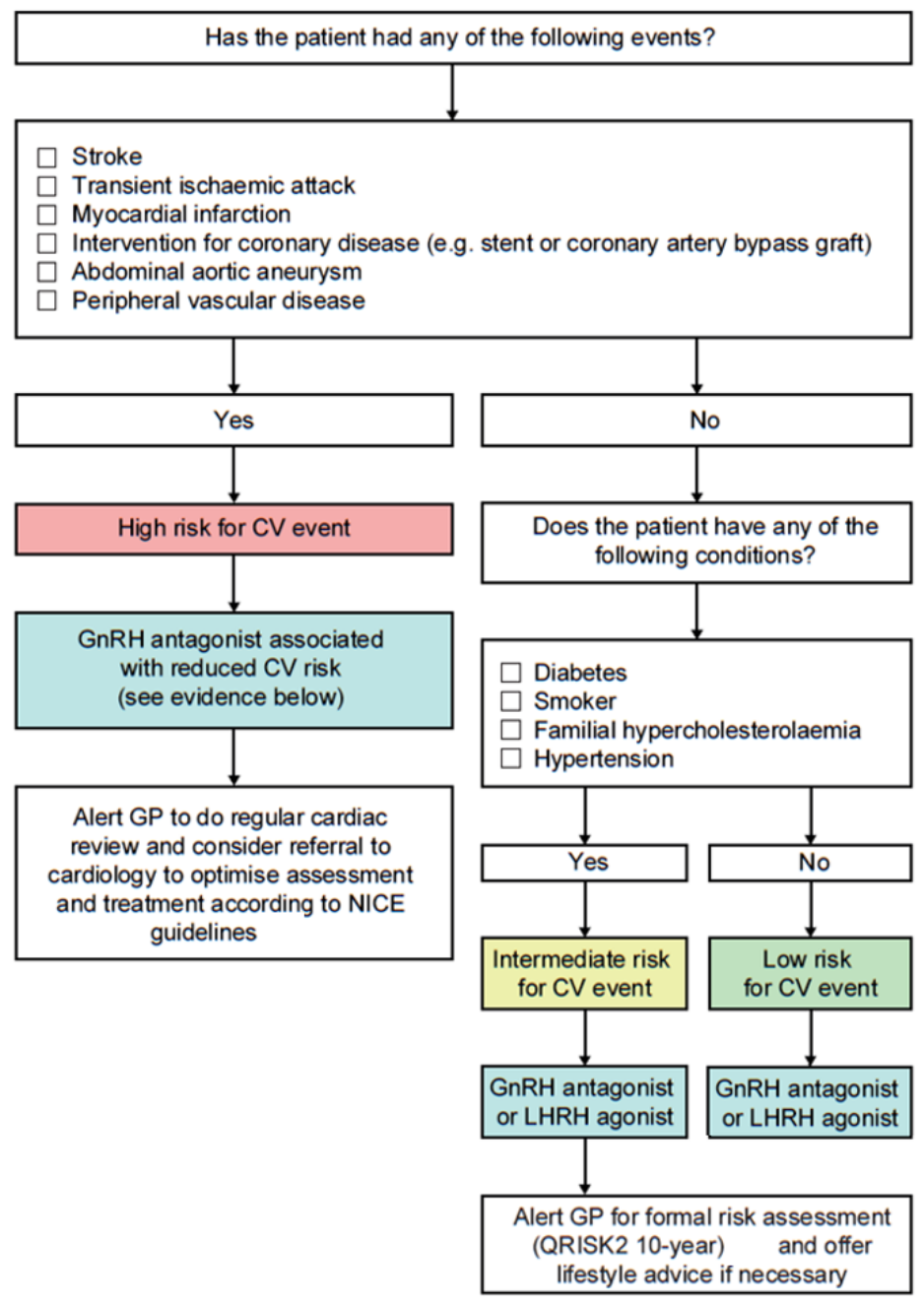

Figure 2

Cardiovascular risk assessment tool 


\begin{tabular}{|c|c|c|}
\hline Screening and monitoring & Lifestyle changes & $\begin{array}{l}\text { Pharmacological } \\
\text { interventions }\end{array}$ \\
\hline $\begin{array}{l}\text { - Measuring of lipids } \\
\text { (including triglycerides) } \\
\text { - HbA1c } \\
\text { - Fasting glucose } \\
\text { - Total cholesterol/HDL- } \\
\text { cholesterol ratio from a } \\
\text { non-fasting blood } \\
\text { sample } \\
\text { - LFT for fatty liver } \\
\text { changes } \\
\text { - U and E test for renal } \\
\text { function } \\
\text { - Blood pressure control } \\
\text { - BMl and waist } \\
\text { measurement } \\
\text { - Selected family history }\end{array}$ & $\begin{array}{l}\text { - Smoking cessation } \\
\text { - Improved diet } \\
\text { - Regular exercise } \\
\text { - Reduced alcohol } \\
\text { consumption } \\
\text { - Stress management }\end{array}$ & $\begin{array}{l}\text { - ACE inhibitors } \\
\text { - High intensity statin } \\
\text { therapy for } \\
\text { hyperlipidaemia } \\
\text { Patients with diabetes } \\
\text { - Metformin } \\
\text { - DPP-4ls } \\
\text { - GLP-1RAs } \\
\text { - SGLT-2Is }\end{array}$ \\
\hline \multicolumn{3}{|c|}{$\begin{array}{l}\text { ACE, angiotensin converting enzyme; BMI, body mass index; DPP-4ls, dipeptidyl } \\
\text { peptidase-4 inhibitors; Hb, haemoglobin; GLP-1RAs, glucagon-like peptide-1 receptor } \\
\text { agonists; HDL, high-density lipoprotein; LFT, liver function test; SGLT-2Is, sodium-glucose } \\
\text { co-transporter } 2 \text { inhibitors; U and E, urea and electrolytes }\end{array}$} \\
\hline
\end{tabular}

\section{Figure 3}

Box 1 Key CV risk screening and monitoring strategies and lifestyle and pharmacological interventions

\section{Supplementary Files}

This is a list of supplementary files associated with this preprint. Click to download.

- SupplementaryFigure1Final06.04.21.docx 